\title{
EDUCATION, TECHNOLOGICAL CHANGES AND ECONOMIC DEVELOPMENT OF BOSNIA AND HERZEGOVINA
}

\author{
Dr. Goran Popović, University of Banja Luka, Faculty of Economics, Republic of Srpska \\ E-mail: goran.popovic@ef.unibl.org \\ Dr. Ognjen Erić, University of Banja Luka, Faculty of Economics, Republic of Srpska \\ E-mail: ericognjen@yahoo.com \\ Dr. Stanko Stanić, University of Banja Luka, Faculty of Economics, Republic of Srpska \\ E-mail: stanko.stanic@ef.unibl.org \\ Dr. Milenko Krajišnik, University of Banja Luka, Faculty of Economics, Republic of Srpska \\ E-mail: milenko.krajisnik@ef.unibl.org
}

\section{ART I C LE INFO \\ Original Research \\ Received: July, 16.2019. \\ Revised: August, 08.2019. \\ Accepted: August, 17.2019. \\ doi:10.5937/IJCRSEE1902077P \\ UDK \\ $330.341 .1(497.6)$ \\ 330.45}

\section{Keywords:}

education,

technological readiness,

innovations,

economic development,

Bosnia and Herzegovina.

\section{A B S T R A C T}

Accumulation of knowledge, the role of education and innovations in the stimulation of economic development are important for understanding the endogenous theory of growth. The aim of this paper is to determine the strength and direction of relations between independent variables of education, technological development, innovations, foreign investments and the economic growth of Bosnia and Herzegovina $(\mathrm{B} \& \mathrm{H})$. The relations between variables are assessed by multiple regression analysis for the period 2005 - 2017. GDP per capita (pc), as a measure of general wellbeing and economic development is a dependent variable of the regression model. Education Years Average, Technological readiness and Innovations are explanatory variables, whereas Foreign investments and Macroeconomic environment are control variables. The results indicate statistical significance of variables Education Years Average, Technological readiness and Innovations. The first two variables indicate a positive effect on the economic development, whereas Innovations have a negative effect on the economic development. The control variables are statistically insignificant. Therefore, more investment is recommended in the field of education, science and research. Institutions should be more developed and scientific-research systems should be harmonized with the European Union. It is the only way for B\&H to be able to respond to global challenges when it comes to competitiveness, export and the GDP growth. Examples and experiences of this country can be useful for research activities in similar post-transition countries.

(C) 2019 IJCRSEE. All rights reserved.

\section{INTRODUCTION 1.1. General approach}

Bosnia and Herzegovina $(\mathrm{B} \& \mathrm{H})$ is a small developing country. According to Kuznets (1960), small countries are those with less than 10 million inhabitants, while the Corresponding Author

Dr. Goran Popović, University of Banja Luka, Faculty of Economics, Republic of Srpska

E-mail: goran.popovic@ef.unibl.org

This work is licensed under a Creative Commons Attribution - NonCommercial - NoDerivs 4.0. The article is published with Open Access at www.ijcrsee.com
World Bank and IMF hold small countries to be those having less than 1.5 million inhabitants. In 2017, there were 144 small countries (World Meters, 2017). In addition to the fact that transition has not been completed yet, B\&H has a complex constitutional-legal structure made up of two entities, the Federation of B\&H and the Republic of Srpska.

The educational system in B\&H has not been fully reformed nor has it been harmonized with the European Union (EU) system and policies. The EU, as a global actor, allocates significant funds to education, research and development (Erić, O., 2017). The $\mathrm{EU}$ is in the process of structural changes such as the implementation of EU 2020 -A Strategy 
for Smart, Sustainable and Inclusive Growth (Popović, G., 2016). The term "smart" refers to acquisition of new knowledge, including studying, lifelong learning, etc. The focus is on new technologies, innovations, ICT development, robotics, biotechnology, space exploration, etc.

The main aim of this research is to assess the impact of education, technological changes and innovations on the economic development of B\&H. This implies that the main research subject of this paper is to establish the relation between technical progress and GDP growth per capita (pc).

Bosnia and Herzegovina does not meet EU standards or goals of the Strategy 2020. However, strategies and planning in the field of education and research are based on the European standards. The goal is to bring educational, scientific and research structure of B\&H closer to the European model.

The economic development affects the system of education, science and research, which are ever more considered to be the condition for competitive production of goods and services. Nowadays, modern production requires appropriate accumulation of knowledge. Therefore, the assessment of impact of education, science, technological readiness, innovations and other forms of knowledge on the economic growth contribute to better understanding and implementation of policies and measures in the above indicated sectors.

Nowadays, in the era of globalization, democratic, developed and stable societies have ensured good quality systems of education, science and R\&D. In such societies, economic and overall development depends on the synergy of impacts of all the factors mentioned above.

\subsection{Literacy Review}

The economic development and wellbeing are primary goals in modern states, assuming continuous and high rates of economic development. A global indicator of economic growth expresses changes in gross domestic product (GDP, output) in aggregate or pc. Traditionally, capital and work-force are the factors that create GDP:

$$
\mathrm{Y}=\mathrm{f}(\mathrm{K}, \mathrm{L})
$$

Traditional theory of economic growth has been contributed by the Nobel Prize winner Solow, R. (1956). He introduced technical progress (accumulation of knowledge, technological progress), which is a constituent factor of long-term economic growth. However, technological progress is given as an exogenous model in Solow's model; therefore, this key factor that determines the rate of economic growth is not explained in the model at all. The new or endogenous theory of growth offers somewhat different explanation of economic growth compared to neoclassical theory. This theory in the growth models makes the technical progress endogenous. Foundations of modern endogenous theory of economic growth are being investigated by many researchers. Paul Romer, one of the founders of endogenous theory, received the Nobel Prize in Economics (2018), which confirmed the importance of education, knowledge and technological progress in the economic growth. Besides Romer (1994), significant contribution to development of this theory was given by his mentor Lucas, R. Jr. (1988), as well as by Grossman and Helpman (1991), Aghion, Ph. and Howitt P. (1992), and many other researchers.

Lucas Jr, R. E. (2015) considers that human capital contribution to economic growth is reflected in the affirmation of production function (economy of supply). According to Lucas, the human capital affects the economic growth outside formal education. Moreover, the human capital is considered to be the nucleus of growth. He argues that more skills are acquired when interacting with people rather than in formal education (learning by doing process). Greif and Mokyr (2017) base their approach to economic development on the importance of cognitive rules in two directions. One is the rise of the modern state with its legitimacy based on consent, and the other one is the rise of modern science-based technology. The second one is the product of the scientific revolution and the Enlightenment.

In addition to theoretical approaches, there are numerous empirical studies on the connection between education, technological progress and economic development.

Saviotti, Pyka and Jun (2016) identify that education brings positive impact on social mobility and increases the population share in the upper social class. These results are based only on education without taking into account any wealth effects. Hanushek (2016) states that differences in cognitive skills - the knowledge capital of countries - can explain most of the differences in growth rates across countries, but adding more years of schooling without increasing cognitive skills has historically brought small systematic influence on 
growth. Wang and Liu (2016) stipulate that educated human capital has a positive impact on the economic growth. Higher education notably affects the economic growth, while primary and secondary education does not have a significant impact on the economic growth. Lauder (2015) argues that at least two fundamental gaps exist in education and economic development. The first one refers to the failure to identify the effects of the global economy on states and, in particular, the demand for educated labor. Grant (2017) argues that ignoring the economic dimension of education would endanger the prosperity of future generations, with wide-spread repercussions on poverty, social exclusion, and sustainability of social security systems. Surveying the most recent empirical evidence, Woessmann (2016) shows the crucial role of education for individual and societal prosperity. He believes that education is the leading determinant of economic growth, employment, and earnings in modern knowledge-based economies.

Innovations are considered to be the basis of economic growth and wellbeing. This hypothesis was investigated by Škare and Tomic (2014) in the analysis of effects of the so-called third industrial revolution for OECD countries for the period 1950-2013. They relate innovations and the growth of productivity. Given that GDP depends on technological changes, they assessed effects of technological shocks on GDP (in aggregate and pc) and labor productivity growth. It was proved that technological innovations significantly affect the growth, invoking higher future expectations.

Fu et al. (2011) studied economic development by assessing autochthonous and foreign efforts made in innovations and technological changes. This study has shown that benefits of liberalization and effects of technological developments, as global positive externalities, may be achieved only in modern, national innovation systems and with incentives. This clearly points out the need for complementarity of domestic and foreign innovation systems.

The relation between the economic growth and technological progress was investigated by Tomić (2012). He considers that innovations in developed countries are the result of technological progress and an unavoidable factor of economic development.

Pecea, Ecaterina, Oros and Salisteanu, (2015) identify a positive relationship between economic growth and innovations by using multiple regression models and the sample of CEE countries where long term economic growth is affected by the innovation potential of an economy. Aghion, Akcigit and Howitt (2015) state that the Schumpeterian paradigm of more creative destruction implies stronger destruction of jobs, which reduces the wellbeing of currently employed workers. On the other hand, more creative destruction implies new job creation and higher growth rate, both of which should enhance wellbeing.

Toivanen and Vaananen (2016) studied the causal effect of MSc engineering education on invention, using data on the U.S. patents, the Finnish inventors and the distance from the nearest technical university as an instrument. They have identified favorable effect of engineering education on the tendency of the patent and negative OLS bias.

Freeman and Soete (2009) observe positive effects of technological changes in the context of positive externalities arising from the use of computer technologies and growing interests of the public and private sectors for investments in science and technology. Investigations of Kesici Çalışkan (2015) also indicate dependence of economic growth on scientific and research institutions, but also on the wellbeing of the society. Similar results got Kochetkov, Larionova and Vukovic D. B. (2017) when they tested impact of the universities on economic growth.

In his research, Freeman (2013) analyzed dynamics and features of global technological changes and their effect on the GDP growth. He selected the growing interest in the economy of innovations due to economic reasons and general goals. Malerba and Cantner (2006) provide an overview of development and evolution of industrial structure in the context of the evolution of Schumpeterian tradition. These processes are followed by changes in knowledge, technologies, innovations and institutions.

Aghion and Antonin (2018) have shown positive impact of innovation and creative destruction on social mobility. Acemoglu and Cao (2015) extended the basic Schumpeterian endogenous growth model by allowing incumbents to undertake innovations to improve their products, while entrants engage in more "radical" innovations to replace incumbents.

Finally, both the growth and liberalization of the world trade are processes that develop in parallel with global externalities growth. They are generated by continuous technical and technological changes. 


\section{MATERIALS AND METHODS}

Several data sources were used to assess relations between the variables. Global Competitiveness Reports from World Economic Forum (WEF) was used as the main source, wherefrom we retrieved: Innovations as the score value, Technological readiness and Macroeconomic environment. Data on dependent variable GDP pc and control variable Foreign Direct Investments (FDI) were retrieved from the World Development Indicators, World Bank official (WB) data-base.

A dependent variable GDP pc is a general measure of wellbeing, of living standard and the level of development. The above indicated source was used to analyze this indicator, according to the purchasing power parity for the base year of 2011.

Education Years Average, as an explanatory variable in the model, presents an average number of years of education referring to the entire population (data retrieved from the official Internet site, the United Nations Development Program, Human Development Report).

Innovations as an explanatory variable in the model express the value of the score stated in the Global Competitiveness Report.

The explanatory variable Technological readiness in the model presents the ability to adopt technological changes. It is expressed in the value of the score, where higher value presents a higher rank in the global innovation index.

The FDI inflow is a control variable. It is used in the model as a relative indicator, compared to GDP. Otherwise, FDI is considered to be a significant driver of economic development. This particularly refers to developing countries such as $\mathrm{B} \& \mathrm{H}$, which records chronic deficit in investments. Therefore, attracting FDI is one of the ways to accelerate the GDP growth, in aggregate and pc.

Macroeconomic environment is a standard factor to assess quality of an activity that the World Economic Forum has been analyzing and publishing for many years in the Global Competitiveness Report. In this paper, the rank of a country is used for the analyses whereby a higher rank indicates a lower position of the country.

Data on all the variables for B\&H were collected within the period 2005-2017.

Following the investigations conducted by Pecea et al., 2015, and then Wang and Liu (2016), we used multiple regression analysis in this paper. The multiple linear regression model was used to assess the relationship between dependent, explanatory and control variables. The aim of this method is to explore the connection between variables and to quantify the statistical significance of certain variables. The regression model shows an average composition of variation of the investigated incidence. The multiple regression model has the following equation (Koop, G., 2003):

$$
y=\beta 0+\beta 1 \times 1+\beta 2 \times 2+\beta 3 \times 3+\ldots+\beta k x k+\varepsilon
$$

where $\mathrm{x}$ - means independent variable, $\mathrm{y}$ - dependent variable, $\beta$ - regression parameter and $\varepsilon$ is residual. The aim of regression analysis is to predict some values of y (dependent variable, GDP per capita in this paper), for a certain value of $x$ (explanatory variables: The Education Years Average, Technological readiness and Innovations. The control variables are Foreign investments and Macroeconomic environment in this paper. The ordinary least square (OLS) method minimizes squares sum residual in order to estimate the unrecognized parameters in the sample. Furthermore, the OLS method estimates and minimizes the sum of squared residuals. The estimation of $\beta 1$ and $\beta 2$ is interpreted so that y (dependent variable) could be predicted with the change of $x 1$ and $x 2$. The reliability of the model was accepted on the $\mathrm{p}$-value and $\mathrm{R}$ square (adjusted $\mathrm{R}$ square). The p-value should be less than 0.05 (in some estimation the level could be higher -0.10 or 0.15 ). The higher value of adjusted $R$ square means that the model is more reliable.

\section{RESULTS}

The regression analysis was conducted in the program package XLStat. Table 1 presents the obtained results in three sections. The first section provides the results of sum statistics i.e. the quality of the entire model.

Determination coefficient R Square (R2) amounts to 0.92 and indicates that $92 \%$ of changes in the dependent variable (GDP pc) are explained by the common effect of explanatory variables in the model. Therefore, the summary results of the regression analysis show that statistical model is an appropriate model for the explanation of dependent variable changes compared to the overall effect of independent variables.

The results in the second section are in direct correlation with the first section and present the analysis of the variance through the relationships between the sum of least square regression and residual regression with 
Popović, G., Erić, O., Stanić, S. \& Krajišnik, M. (2019). Education, technological changes and economic development of Bosnia and Herzegovina, International Journal of Cognitive Research in Science, Engineering and Education (IJCRSEE), 7(2), 77-86

the number of degrees of freedom (values in which parameters can freely vary). The results of $F$ test in the analysis of variance (ANOVA) show the test value of 16.74 with probability below 5\%, meaning that statistical conclusions of the model are significant.

The third section presents values of explanatory and control variables coefficients in the model, the value of t test and probability i.e. individual statistical significance in explaining a dependent variable. The results indicate statistically significant variables in explaining dependent variables at the level of 5\%: The Education Years Average, Innovations and Technological readiness. The Education Years Average and Technological readiness show positive direction, while Innovations are inversely proportional compared to GDP pc change. In addition, the third section shows that the observed coefficients of explanatory variables are small.

The control variables Macroeconomic environment and FDI net inflow are not statistically significant in individual explanation of changes in GDP pc in Bosnia and Herzegovina.

Table 1. Regression analysis results

\begin{tabular}{|c|c|c|c|c|c|}
\hline \multicolumn{6}{|c|}{$\begin{array}{l}\text { Regression } \\
\text { Statistics }\end{array}$} \\
\hline \multicolumn{5}{|c|}{ Multiple R } & 0,96 \\
\hline \multicolumn{5}{|l|}{ R Square } & 0,92 \\
\hline \multicolumn{5}{|c|}{ Adj. R Square } & 0,87 \\
\hline \multicolumn{5}{|l|}{ St. Error } & 0,02 \\
\hline \multicolumn{6}{|l|}{ Anova } \\
\hline & $D f$ & $S S$ & $M S$ & $F$ & $\begin{array}{l}\text { Sign. } \\
\text { F }\end{array}$ \\
\hline $\begin{array}{l}\text { Regres- } \\
\text { sion }\end{array}$ & 5 & 0,0387 & 0,008 & 16,8 & 0,001 \\
\hline Residual & 7 & 0,0032 & 0,000 & & \\
\hline Total & 12 & 0,0420 & & & \\
\hline
\end{tabular}

\begin{tabular}{|c|c|c|c|c|}
\hline & Coeff. & $\begin{array}{l}\text { St. } \\
\text { Error }\end{array}$ & $t$ Stat & $\begin{array}{c}P \\
\text { value }\end{array}$ \\
\hline Intercept & 3,9 & 0,10 & 37,3 & 0,00 \\
\hline $\begin{array}{l}\text { Education } \\
\text { Years Average }\end{array}$ & 0,029 & 0,01 & 2,36 & 0,05 \\
\hline Innovation & $-0,158$ & 0,05 & $-3,22$ & 0,01 \\
\hline $\begin{array}{l}\text { Technological } \\
\text { readiness }\end{array}$ & 0,064 & 0,02 & 3,01 & 0,01 \\
\hline $\begin{array}{l}\text { Macroeconomic } \\
\text { Enviroment }\end{array}$ & 0,001 & 0,00 & 1,55 & 0,16 \\
\hline$F D I$ & 0,01 & 0,00 & 1,55 & 0,16 \\
\hline
\end{tabular}

The regression analysis results show interdependence between the constituents of accumulated knowledge and economic growth. The statistical analysis confirms the conclusion that the situation in the fields of education, science, research and innovations in $\mathrm{B} \& \mathrm{H}$ is not favorable. This was confirmed by the comparative WEF analysis, where global competitiveness indices have been published for most countries (GCI). In 2016, out of 137 countries, $\mathrm{B} \& \mathrm{H}$ is on the $103^{\text {rd }}$ position (The Global Competitiveness Reports, 2017-2018). The global index is the sublimate pillar for various social fields. Pillars referring to education, science and research significantly deviate from an average rank. The pillar Primary education is in $56^{\text {th }}$ position and is ranked higher than the overall index for B\&H. The Quality of primary education is in $84^{\text {th }}$ position, and the Primary education enrolment rate is in $43^{\text {rd }}$ position. The pillar Higher education and training has been ranked slightly above the average, in $91^{\text {st }}$ position. It includes: Secondary education enrolment rate in the $78^{\text {th }}$ position and Quality of the education system in $131^{\text {st }}$, Quality of math and science education in $97^{\text {th }}$ and Quality of school management in $122^{\text {nd }}$ position. The regression analysis shows that GDP change is positively affected by technological readiness, given that the pillar Technological readiness takes the $69^{\text {th }}$ position. This pillar includes Availability of the latest technologies - 82 $2^{\text {nd }}$ position, Firm-level technology absorption - $92^{\text {nd }}$ position while FDI and technology transfer takes $107^{\text {th }}$ position. Therefore, WEF considers FDI to be technical-technological dimension and the growth driver. Innovations take the worst position - $123^{\text {rd }}$ with Quality of scientific research institutions in $106^{\text {th }}$ position and Company spending on R\&D in $126^{\text {th }}$ position. WEF introduced a new GCI 4.0 concep- 
tualized at the Fourth Industrial Revolution (4IR). It includes new moments/indicators: human capital, innovativeness and better use of technologies. It promotes education, science $\&$ technology, innovativeness \& research as economic growth factors. According to GCI 4.0 in $2018, \mathrm{~B} \& \mathrm{H}$ was ranked in $91^{\text {st }}$ position out of 140 countries (The Global Competitiveness Reports, 2018). The pillar ICT adoption is in $86^{\text {th }}$ position, Skills in $87^{\text {th }}$, and Innovations capability in $114^{\text {th }}$ position. Indicators within the pillar Skills are not homogeneous (Mean years of schooling takes $74^{\text {th }}$ position, Skillset of graduates $133^{\text {rd }}$, Digital skills among population $88^{\text {th }}, R \& D$ expenditures $91^{\text {st }}$, Quality of research institutions $85^{\text {th }}$ etc.). Obviously, indicators referring to Skills and/or Higher education and training correlate with the average rank for B\&H.

Differences in contribution of certain fields, institutions and policies have an impact on the situation, development and planning in education, science and research. The future objectives should be innovativeness, transfer of technologies, technological readiness and adoption of the leading technologies, particularly in application of computer techniques, robotics, biotechnology, etc.

\section{DISCUSSION}

The global world is undergoing fast changing processes. The changes are so dynamic that social sciences in certain fields are lagging behind in terms of technical, biotechnological and other researches. For example, although artificial intelligence technologies are greatly developing, research works on their implications in wider social context are delayed. The situation is similar in other advanced technologies: IT, bio-technologies, exploration of the space, etc. Although global changes may be adverse in social or other spheres, they are still part of general prosperity. Nowadays, the need for scientific considerations of global and national framework is required to determine the relation between relevant social factors. Priorities have also changed. Ideological, geo-political and geostrategic issues used to be the priority, but these days the priorities are current changes in education, science, research, development, technology and innovations. These issues create the picture of the world in the XXI century.

Knowledge has become a modern paradigm that dominates, connects the modern world and breaks the established ideological- political borders. Accumulated knowledge is the human capital in fact, which is the growth factor in the core of developmental economic theory. Many relevant authors consider the accumulated knowledge as the sublimate of education, science, research and innovations. Thanks to global networks, the scientific research works have become available to researchers and citizens. Practical application of research and innovations is higher and more time is needed to develop a new product or service. Hekkert, Suurs, Negro, Kuhlmann and Smits (2006) have proved that the innovation system is an important factor of technological changes. The evolution of innovation system is in parallel with technological changes. Hence, they have proposed monitoring of the process of functioning and development of the system of innovations. This group of authors suggests the scientific method of systemic mapping of innovation processes that affect technological changes. Sometime before, Dosi, Pavitt and Soete (1990) analyzed innovation theories, practices and politics. They chose five functions of new innovation processes. They emphasized implementation of strong innovation systems, research platforms and strengthening of infrastructure for development of strategic intelligences. Their attitudes are still present in the era of artificial intelligence, fifteen years later.

The economic interest is at the core of every human activity. Investigations and relevant theories indicate that almost all activities in fields of education, science and technological development, innovations and technology are economically motivated. Firms, institutions and individuals endeavor to accumulate knowledge with the ultimate goal of increasing profit, to ensure GDP growth, and to increase the volume of trade.

Technical and technological development goes hand in hand with domestic and international trade development. Cooperation and joint investments lead to consolidation of capital for the needs of research and development. Trade liberalization accelerates the process of technological changes. Dosi, Pavitt and Soete (1990) analyzed economic and technical changes in the context of trade development. They investigated technology gaps in the context of international trade. They have provided an overview of technological progress and economic dynamics. Several economists, a few of them who are the Nobel Prize winners, have investigated fundamental aspects of economic development related to education, science and technology, state of innovativeness, 
and more. Some scientifically and empirically confirmed mathematical models of growth show that technical progress could be one of the crucial economic development drivers.

In their middle and long term plans, some developed countries plan to invest more money into new technologies that would eventually later lead to higher GDP growth. Because of that, the developed and developing countries invest resources in human capital. In relative terms, the invested resources vary by country. Regarding Europe, Scandinavian countries and Germany invest most. Strategy 2020 foresees that public and private investments into science and research will grow from about $2 \%$ to at least 3\% of GDP until 2020. This was first achieved by Sweden and Austria. Slovenia allocates $2 \%$ of GDP into research and development (2016), whereas Croatia, Serbia and Bulgaria allocate $0.75-1 \%$. Bosnia and Herzegovina invests below $0.2 \%$. In relative values, Israel with the investment of above $4 \%$ GDP and South Korea are the world leaders. In absolute, along with the USA, investments grow in China, which has become the global technological leader in many fields of science and technology, with investment of 300 billion dollars per annum.

The B\&H investments into scientific research are minor. The investment determines the quality of scientific and research institutions. The education system is facing problems, although the situation is a bit better than before. The system has been created in a complex constitutionallegal organization, a unique one in the world (the state consists of two entities and three nations). Education is under the competence of entities, but certain functions have been transferred onto the B\&H level. Some reforms have been implemented in primary, secondary and higher education, but the system has not yet been harmonized with the EU standards and practice. Private investors invest into education, particularly in higher education. Due to institutional weaknesses, good intentions have turned into contradiction. Corruption, political instability, migrations of young and educated experts, unemployment and labor market structural problems resulted in decline of education quality at all levels. The structure of those seeking jobs on the labor market is unfavorable. Institutions fail to plan output staff profiles and do not invest in retraining thus distorting the economic and political stability. Reforms in this sector are necessary for faster economic growth.

However, systems of education, science and technological development, innovations and technology are based on experiences of the former SFRY. In the former joint state, B\&H used to develop "heavy" and defense industry, wood industry and energetics. Huge business systems such as UNIS, Energoinvest, Šipad, Soko, RMK and others were developed. These business systems invested a lot into scientific research. Parts of that research culture and infrastructure are still functioning.

Foreign investments are the source of investments in a national economy and they present an indicator of readiness of domestic firms to adopt foreign technologies (Spitsin, Mikhalchuk, Spitsina and Vukovic, 2018). In the examples of transition countries like Croatia in the period 2001-2010, Bezić and Karanikić (2014) investigated the impact of technologies on the economic growth. FDI is seen as an efficient way of import and transfer of new technical-technological solutions. By analyzing the effects of foreign investments and transfer of technologies on GDP, they confirmed a positive relation between FDI and variables: transfer of technologies and GDP growth.

FDI in B\&H is influenced by domestic resources offered, particularly qualified and highly educated work force. Some researchers emphasize the significance of the labor force price, but some of them prefer countries with higher qualified work force rather than those with cheap workforce. This implies the connection between the system of education, scientific research, innovativeness and the FDI inflow (Popović G. and Erić, O., 2018).

Further on, stable macroeconomic environment is important for the affirmation of knowledge. Otherwise, costs of education, science and research are reduced.

Therefore, along with key variables that determine the system of education, science $\&$ technological development, innovations $\&$ technological readiness, multidisciplinary control indicators are also significant. These indicators are FDI inflow and the situation in the macro-economic environment. By responding to the hypothesis on the impact of these variables on GDP growth, we will, de facto, provide answer to the question: Does B\&H need reforms where knowledge and human capital are treated as strategic factors of development?

\section{CONCLUSION}

Education, science and research affect technological changes and economic devel- 
opment. This has been proved by respectable scientific fundus, partially presented in the previous studies. This study is based on the hypothesis that the independent variables: Innovation, Education Years Average and Technological readiness affect the economic development of Bosnia and Herzegovina. Logarithmic value of GDP pc, which is an indicator of the economic growth and well-being, is the dependent variable in the regression model. To "foster" the model and to achieve higher overall significance, we included the control variables: Foreign direct investmentnet inflows (as \% of GDP) and Macroeconomic environment. We applied the multiple regression method. Available and scientifically relevant time series for Bosnia and Herzegovina in the period 2005-2017 were used as input data.

The regression analysis results indicate the statistical significance of the following variables: Education Years Average, Technological readiness and Innovation. However, the intensity and directions of the variable changes differ. The impact coefficients of Education and Technological readiness show weak but positive impact on GDP pc growth. Both variables show the situation in education and scientific structures, whereby Technological readiness is connected to technological changes and the situation in industry. The obtained results correlate with the results obtained in previous studies (Grant 2017; Woessmann, 2016; Freeman and Soete, 2009). The third and the most important variable - Innovation, also shows significance, but its relation to GDP pc is negative. Namely, Innovation negatively affects changes in GDP pc. Previous studies mainly confirm positive impact of innovation on productivity and growth (Pecea et al., 2015, Wang and Liu, 2016). We have expected this result, given that Bosnia and Herzegovina invests minor funds into science, research and innovation, In addition, this country lacks the necessary institutional structure and legislation when it comes to innovation, protection of patents, copy rights, etc. Therefore, multiple regression analysis has proved that Education Years Average and Technological readiness contribute to higher rate of the economic growth in Bosnia and Herzegovina, while Innovations slow down the GDP pc growth trend.

The analysis show that the impact of the following control variables FDI and Macroeconomic environment is not statistically significant, although the variables increase, to a certain extent, the overall significance of the model. Finally, the high determination coef- ficient proves that the intensity of dependent variable changes is highly determined by the action of explanatory and control variables.

Results confirm that Bosnia and Herzegovina has problems in the system of education, in scientific research and innovations. Nevertheless, small positive contributions of education and technological readiness indicate the potential and reserves of this country when it comes to human capital and accumulation of knowledge. These resources could be put into the function of economic development through the process of reforms and higher investments into education, science and research. The results lead to the conclusion that Bosnia and Herzegovina should resolve the deadlocks related to innovations and put them into the function of development.

Comparative analysis results are in correlation with the regression analysis results. Data on education, science and research in Bosnia and Herzegovina are presented in annual WEF Competitiveness reports. According to the reports, $\mathrm{B} \& \mathrm{H}$ is lagging behind the world when measured by the Global Competitiveness Index - GCI. GCI constituent parts are the pillars - education, science and research, which differ in relation to the average rank. The pillar Primary education is better ranked than GCI. Also, pillars Higher education and training, and Technological readiness are better ranked than GCI. On the contrary, FDI \& Technology transfer, and the pillar Innovation are ranked lower, which was confirmed by the regression analysis results. The situation is similar when we apply GCI 4.0 standards, which favor accumulation of knowledge and affirmation of human capital, innovation and use of technologies. Education, science, research and innovation dominate in GCI 4.0 standards, as they are the factors of competitiveness and growth. The pillar ICT adoption is better that the average GCI 4.0, and the same stands for Skills. Innovation capability is below the average, which corresponds to the regression analysis results. The analysis proved that Innovation has a negative impact on GDP pc. In general, the indicators of the pillar Skills are not homogeneous given that educational and scientific-research system in Bosnia and Herzegovina is undeveloped and inconsistent.

The situation in Bosnia and Herzegovina requires a more realistic planning, greater investments and harmonization of the economic system with the system of education, science, research and innovations. There is no competitive production of goods and services 
without accumulation of knowledge. Institutions and politics should play a stronger role, in particular in planning and encouraging development of education, science and research. Along with education, more investments must be allocated to all sectors that generate new knowledge.

Bosnia and Herzegovina should target the growth of innovations, faster transfers of technologies and further fostering of technological readiness. The country must achieve higher level of cooperation with the former SFRY republics, given that the production, educational, scientific and research systems of newly created countries comply with each other. However, reforms of the system of education, science and research should be implemented first and then the legislation should be harmonized with the EU. Common principles of the Strategy 2020 should be followed, regardless of the fact that nominal values of most target indicators for $\mathrm{B} \& \mathrm{H}$ are still elusive.

In the era of globalization, the general aim is to increase investment in education, science, research and innovation growth, better technological readiness and FDI. These are the factors that the social wellbeing depends on in developed countries. Hence, this is the only possible response to global challenges and the method to increase competitiveness, export and GDP. Educational and scientific system in Bosnia and Herzegovina is searching for new politics and reforms. The legislation framework and strategies for education, science and technological development are priorities, but radical increase of financial resources is also very important. Thereby, higher accumulation of knowledge requires an interaction with other sectors: rule of law, protection of intellectual property rights, encouraging companies to undertake research activities and innovations, liberalization, market economy development and democratization of the society.

\section{ACKNOWLEDGEMENTS}

We thank for unselfish support which was given by the management team of the Faculty of Economics, University of Banja Luka in all stages of this research. Nevertheless, we owe special thanks to our colleagues at the Chair of Economic Theory, Analysis and Policy.

\section{Conflict of interests}

The authors declare no conflict of inter-

\section{REFERENCES}

Acemoglu, D., \& Cao, D. (2015). Innovation by entrants and incumbents. Journal of Economic Theory, 157, 255-294. https://doi.org/10.1016/j. jet.2015.01.001

Aghion, Ph., \& Howitt P. (1992). A Model of Growth through Creative Destruction. Econometrica, vol. 60(2), pp. 323-51. https://doi. org/10.2307/2951599

Aghion, P. \& Antonin, C. (2018). Technical Progress and Growth since the Crisis. Revue de l'OFCE, 157(3), 55-68. https://doi.org/10.3917/ reof. 157.0055

Aghion, P., Akcigit, U., \& Howitt, P. (2015). The Schumpeterian growth paradigm. economics, The Annual Review of Economics, 7(1), 557575. https://doi.org/10.1146/annurev-economics-080614-115412

Bezić, H., \& Karanikić, P. (2014). Technology transfer, FDI and Economic Growth in the EU Transition Countries and the Republic of Croatia. Ekonomska misao i praksa, 23(2), 463-482. Retrieved from: https://hrcak.srce.hr/file/193322

Dosi, G., Pavitt, K., \& Soete, L. (1990). The economics of technical change and international trade. New York University Press.

Erić, O. (2017). Analysis of the Effects of the EU Official Development Assistance to the Western Balkans. Acta Economica, 15(26), 123-139. https:// doi.org/10.7251/ace1726123e

Freeman, C., \& Soete, L. (2009). Developing science, technology and innovation indicators: What we can learn from the past. Research policy, 38(4), 583-589. https://doi.org/10.1016/j.respol.2009.01.018

Freeman, Ch. (2013). Economics of industrial innovation. London: Routledge. https://doi. org/10.4324/9780203064474

Fu, X., Pietrobelli, C., \& Soete, L. (2011). The role of foreign technology and indigenous innovation in the emerging economies: technological change and catching-up. World development, 39(7), 1204-1212. https://doi.org/10.1016/j.worlddev.2010.05.009

Grant, C. (2017). The Contribution of Education to Economic Growth. K4D Helpdesk Report. Institute of Development Studies. Brighton, UK.

Greif, A., \& Mokyr, J. (2017). Cognitive rules, institutions, and economic growth: Douglass North and beyond. Journal of Institutional Economics, 13(1), 25-52. https://doi.org/10.1017/ S1744137416000370

Grossman G.M., \& Helpman E. (1991). Innovation and Growth in the Global Economy, MIT Press, Cambridge.

Hanushek, E. A. (2016). Will more higher education improve economic growth?. Oxford Review of Economic Policy, 32(4), 538-552. https://doi. org/10.1093/oxrep/grw025

Hekkert, M. P., Suurs, R. A., Negro, S. O., Kuhlmann, S., \& Smits, R. E. (2007). Functions of innovation systems: A new approach for analysing technological change. Technological forecasting and social change, 74(4), 413-432. https://doi. org/10.1016/j.techfore.2006.03.002

Kesici-Çalışkan, H. (2015). Technological Change and Economic Growth. Procedia - Social and Behavioural Sciences, 195, pp. 649-654. https:// 
doi.org/10.1016/j.sbspro.2015.06.174

Kochetkov D. M., Larionova V. A., Vukovic D. B. (2017). Entrepreneurial Capacity of Universities and Its Impact on Regional Economic Growth. Ekonomikaregiona [Economy of Region], 13(2), 477-488. https://doi.org/10.17059/2017-2-13

Koop, G. (2003). Bayesian Econometrics. John Wiley $\&$ Sons Ltd, The Atrium, Southern Gate, Chichester. West Sussex, England

Kuznets, S. (1960). Economic growth of small nations. In Economic consequences of the size of nations (pp. 14-32). Palgrave Macmillan, London. https://doi.org/10.1007/978-1-349-15210-0_2

Lauder, H. (2015). Human capital theory, the power of transnational companies and a political response in relation to education and economic development. Compare: A Journal of Comparative and International Education, 45(3), 490-493. https:// doi.org/10.1080/03057925.2015.1027515

Lucas Jr, R. E. (1988). On the mechanics of economic development. Journal of monetary economics, 22(1), 3-42. https://doi.org/10.1016/03043932(88)90168-7

Lucas Jr, R. E. (2015). Human capital and growth. American Economic Review, 105(5), 85-88, http://dx.doi.org/10.1257/aer.p20151065

Malerba, F., \& Cantner, U. (2006). Innovation, Industrial Dynamics and Structural Transformation. Journal of Evolutionary Economics 16(1-2). https://doi.org/10.1007/s00191-005-0011-3

Pecea, A.M., Ecaterina, O., Oros, S., \& Salisteanu, F. (2015) Innovation and economic growth: An empirical analysis for CEE countries. Procedia Economics and Finance, 26, 461 - 467. https:// doi.org/10.1016/s2212-5671(15)00874-6

Popović, G. (2016). Ekonomija Evropske unije (eng. Economics of the European Union). Institute for textbooks and teaching aids, East Sarajevo.

Popović, G., \& Erić, O. (2018). Economic development of the Western Balkans and European Union investments. Economic research-Ekonomska istraživanja, 31(1), 1539-1556. https://doi.org/1 0.1080/1331677X.2018.1498009

Romer, P. M. (1994). The origins of endogenous growth. Journal of Economic perspectives, 8(1), 3-22. https://doi.org/10.1257/jep.8.1.3

Saviotti, P. P., Pyka, A., \& Jun, B. (2016). Education, structural change and economic development. Structural Change and Economic Dynamics, 38, 55-68. https://doi.org/10.1016/j.strueco.2016.04.002

Škare, M., \& Tomic, D. (2014). Examining the link between innovation, productivity and growth: A global view. Amfiteatru Economic Journal, 16(36), 606-624. Retrieved from: http://hdl.handle.net/10419/168847

Solow, R. M. (1956). A contribution to the theory of economic growth. The quarterly journal of economics, 70(1), 65-94. https://doi. org $/ 10.2307 / 1884513$

Smits, R., \& Kuhlmann, S. (2004). The rise of systemic instruments in innovation policy. International journal of foresight and innovation policy, 1(1-2), 4-32. https://doi.org/10.1504/ijfip. 2004.004621

Spitsin, V., Mikhalchuk, A., Spitsina, L., \& Vukovic, D. B. (2018). Foreign-owned companies in countries with an unstable economy: The case of the automotive industry in Russia. Journal of International Studies, 11(3). 57-69. https://doi. org/10.14254/2071-8330.2018/11-3/5

Toivanen, O., \& Väänänen, L. (2016). Education and invention. Review of Economics and Statistics, 98(2), 382-396. https://doi.org/10.1162/ rest_a 00520

Tomić, D. $\overline{(2 \overline{0} 12) . ~ R e l a t i o n s h i p ~ b e t w e e n ~ t e c h n o l o g i c a l ~}$ progress and economic growth; Historical overview. In: Quality. Innovation. Future. Moderna organizacija v okviru Univerze v Mariboru Fakultete za organizacijske vede, Maribor, pp. 1290-1299. ISBN 978-961-232-253-3. https:// doi.org/10.18690/978-961-286-020-2.97

United Nations Development Programme (2019). Human Development Reports, Human Development Data. Retrieved from: http://hdr.undp.org/ en/data

Wang, Y., \& Liu, S. (2016). Education, Human Capital and Economic Growth: Empirical Research on 55 Countries and Regions (1960-2009). Theoretical Economics Letters, 6(02), 347-355. https://doi.org/10.4236/tel.2016.62039

Woessmann, L. (2016). The economic case for education. Education Economics, 24(1), 3-32. https:// doi.org/10.1080/09645292.2015.1059801

World Bank (2019). World development indicators. Topic: Economy \& Growth, Infrastructure, Labour, Trade. Retrieved from: http://data.worldbank.org/data-catalog/world-development-indicators

World Economic Forum (2019). The global competitiveness reports 2005-2018. World Economic Forum Geneva. Retrieved from: http://www.weforum.org/en/index.htm

World Meters. (2017). Countries in the world by population. Retrieved January $10^{\text {th }} 2019$. from: www. worldometers.info/world-population/population-by-country/ 